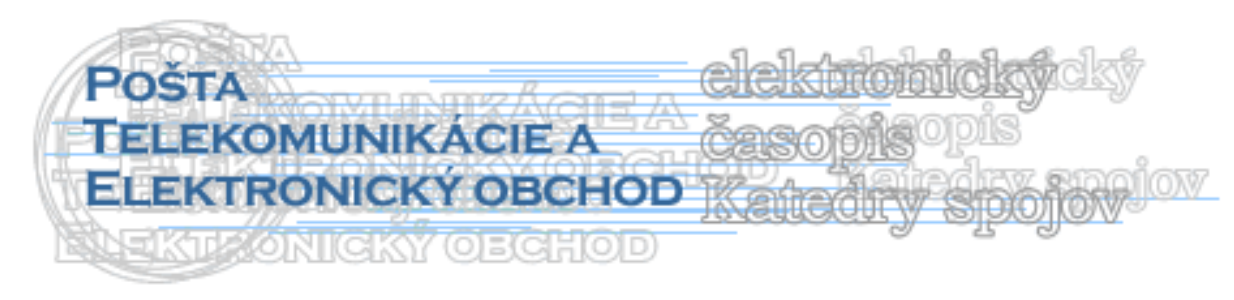

\title{
eBIZ AKO PODPORA INTERNETOVÉHO OBCHODU
}

\author{
Juraj Zachar ${ }^{1}$
}

\begin{abstract}
Abstrakt: Článok opisuje aplikáciu eBiz, ktorá slúži ako podpora pri zakladaní internetového obchodu, poprípade ako možná podpora obchodovania malých a stredných firiem prostredníctvom internetu. Súčast'ou článku je popísat' jednotlivé moduly, z ktorých sa daná aplikácia skladá. Jedná na o moduly eShop, eSupport a InfoLine, ktoré musia byt' vzájomne prepojené pri správnom fungovaní aplikácie.
\end{abstract}

Kl’účové slová: modul, aplikácia.

Úvod

Elektronické podnikanie je dnes moderným fenoménom. Jeho vývoj sa odvíja od šírenia a možností informačných a komunikačných technológií. Všetky firmy, podniky, ktoré sa zaoberajú obchodnou činnost'ou sa dnes len vel'mi t’ažko zaobídu bez prezentácie na internete, bez informačných technológií pomocou ktorých komunikujú so svojimi obchodnými partnermi (dodávatelia, zákazníci). Informačná a komunikačná technológia im poskytuje prostredie, v ktorom sú schopní ovel'a rýchlejšie a lacnejšie uskutočňovat' svoje obchodné aktivity.

\section{Vymedzenie elektronického obchodu}

Elektronický obchod je obchodom, pri ktorom komunikácia medzi účastníkmi prebieha čiastočne, alebo úplne pomocou počítačových sietí. Elektronický obchod môžeme chápat' v širšom a užšom poňatí.

- $\mathrm{v}$ užšom poňatí ho chápeme ako elektronické nástroje pre podporu a realizáciu obchodných vzt'ahov (zahrňujeme sem tvorbu ponuky, reklamy a marketingu).

- v širšom poňatí ho berieme ako elektronické nástroje zahrňujúce aj vlastné činnosti podnikatel'a ako sú: výskum, vývoj, výroba, zásobovanie materiálom, logistika, administratíva, vedenie účtovníctva atd'. [1]

V elektronickom obchodovaní umožňuje informačno-telekomunikačná technológia realizovat' celú nákupnú transakciu v elektronickej podobe. Jediná zložka, ktorú nie je možné uskutočňovat' digitálne je distribúcia tovaru.

Internetový obchod predstavuje určité virtuálne prostredie, kde predávajúci môžu ponúkat' produkty a služby. Internetový obchod má danú určitú štruktúru. Skladá sa zo základných (povinných) prvok a volitel'ných (doplnkových prvkov).

\footnotetext{
${ }^{1}$ Ing. Juraj Zachar., Žilinská univerzita v Žiline, Fakulta Prevádzky a ekonomiky dopravy a spojov, Katedra spojov, Univerzitná 1, 01026 Žilina, email: juraj.zachar@fpedas.uniza.sk
} 
Základné prvky internetového obchodu:

- Katalóg produktov a služieb

- Sprievodca objednávkou

- Nákupný košík

- Sprievodca nákupom produktu

$\Rightarrow$ Výber typu platby

$\Rightarrow$ Spresnenie miesta dodania

$\Rightarrow$ Zobrazenie kompletne vyplnenej objednávky so žiadost'ou o potvrdenie transakcie.

- Zákaznícke konto s prehl'adom objednávky a dodaného tovaru

Okrem základných prvkov, ktoré sú dôležité pre každý internetový obchod, existuje aj celá rada podporných, doplnkových funkcií, ktoré vedú ku skvalitneniu predajných aktivít smerom k zákazníkovi. Tieto podporné prvky, môžu viest' k zvýšeniu atraktívnosti daného internetového obchodu a tým aj k zvýšeniu počtu zákazníkov. Medzi doplnkové prvky radíme napríklad viacjazykovú podporu vyhl'adávania služby v katalógoch, rôzne zl'avové akcie a podobne. [1]

\section{Možnosti tvorby internetových obchodov} spôsobmi:

Pri tvorbe www stránok internetového obchodu je možné postupovat' viacerými - vytvorit' internetové stránky obchodu pomocou HTML, PHP, JAVA, WML apod., teda úplne od začiatku (pomocou programátorov, alebo pomocou osôb, ktoré poznajú nástroje na vytvorenie www stránok)

- objednat' si vytvorenie internetového obchodu od subjektu, ktorý tieto služby ponúka

- využit' pre tvorbu internetového obchodu jeden z vel'a programov (produktov), ktoré sa dajú kúpit' a umožňujú bežným užívatel'om vytvorit' www stránky obchodu (v týchto programoch existujú sprievodcovia, ktorí užívatel'a prevedú postupom a nakoniec dôjde k automatickému vygenerovaniu www stránky).

Priblížme si teraz tretí spôsob založenia internetového obchodu a to pomocou programov, ktoré umožňujú bežným užívatel'om vytvorit' www stránku internetového obchodu. Vzhl'adom k tomu, že na trhu existuje vel'a podobných programov, priblížme si produkt eBiz od spoločnosti Firma Software602, a.s.

\section{eBiz}

Je integrovaná rada modulov, určených pre obchodovanie malých a stredných firiem na internete. Moduly sú určené pre zdiel'anie, evidenciu a sledovanie obchodných aktivít prebiehajúcich vo vzt’ahu ku koncovým zákazníkom a obchodným partnerom. Takisto sú tieto moduly určené aj pre technickú podporu zákazníkom, respektíve predpredajnú a popredajnú podporu a predaj tovarom a služieb na internete vo sfére bussines to bussines (B2B), ale aj bussines to customer (B2C).

Produkt eBiz je určený pre podporu obchodných procesov malých a stredných firiem na internete. Aplikácie, ktoré v sebe zahŕňa, sú určené pre chod na Windows 2000/XP Professional v sietiach do 10 staníc (vo väčších siet’ach na Windows 2000 Serveri), alebo na Linux redhat servri 7,1 a vyššom.

eBiz aplikácia sa skladá z niekol'kých modulov a každý z týchto modulov rieši inú čast' elektronického obchodovania (modul eShop, eSupport, InfoLine). Jedine vo vzájomnej previazanosti však dokážu poskytovat' užívatel'om plnohodnotný výsledný efekt. 
Vd’aka premyslenému systému komunikácie medzi jednotlivými modulmi je možné používat' internet pre získavanie nových obchodných kontaktov. Stačí napríklad na firemný web umiestnit' jednoduchý dotazník, alebo miesto pre prihlásenie potenciálnych zákazníkov a každý nový kontakt sa zaradí do vašej databázy kontaktov. Takisto si môžete vopred zvolit', do akej kategórie sa má kontakt zaradit'.

S pomocou eBiz aplikáciou môžete dat' každému zákazníkovi poskytnút' technickú podporu prostredníctvom internetu. Každý zákazník, má možnost' navštívit' tzv. FAQ (Frequently asked questions), teda stránku na ktorej sa riešia otázky spojené s využívaním predávaného produktu alebo služby. Doslovný preklad tohto pojmu znamená „,̌asto kladené otázky“، Pomocou tejto stránky môže firma vel'mi rýchlo a efektívne poskytnút' zákazníkom odpovede, pokial' má zákazník problém s produktom. Tato "znalostná" databáze šetrí hlavne čas a do vel'kej miery aj peniaze. V spolupráci s ostatnými modulmi eBiz aplikácie, môže potom ponúknut' rôzne úrovne technickej podpory pre rôzne skupiny zákazníkov. Aplikácia eBiz sa skladá s nasledujúcich modulov, ktoré sú vzájomne prepojené. InfoLine, eShop, eSupport. [2]

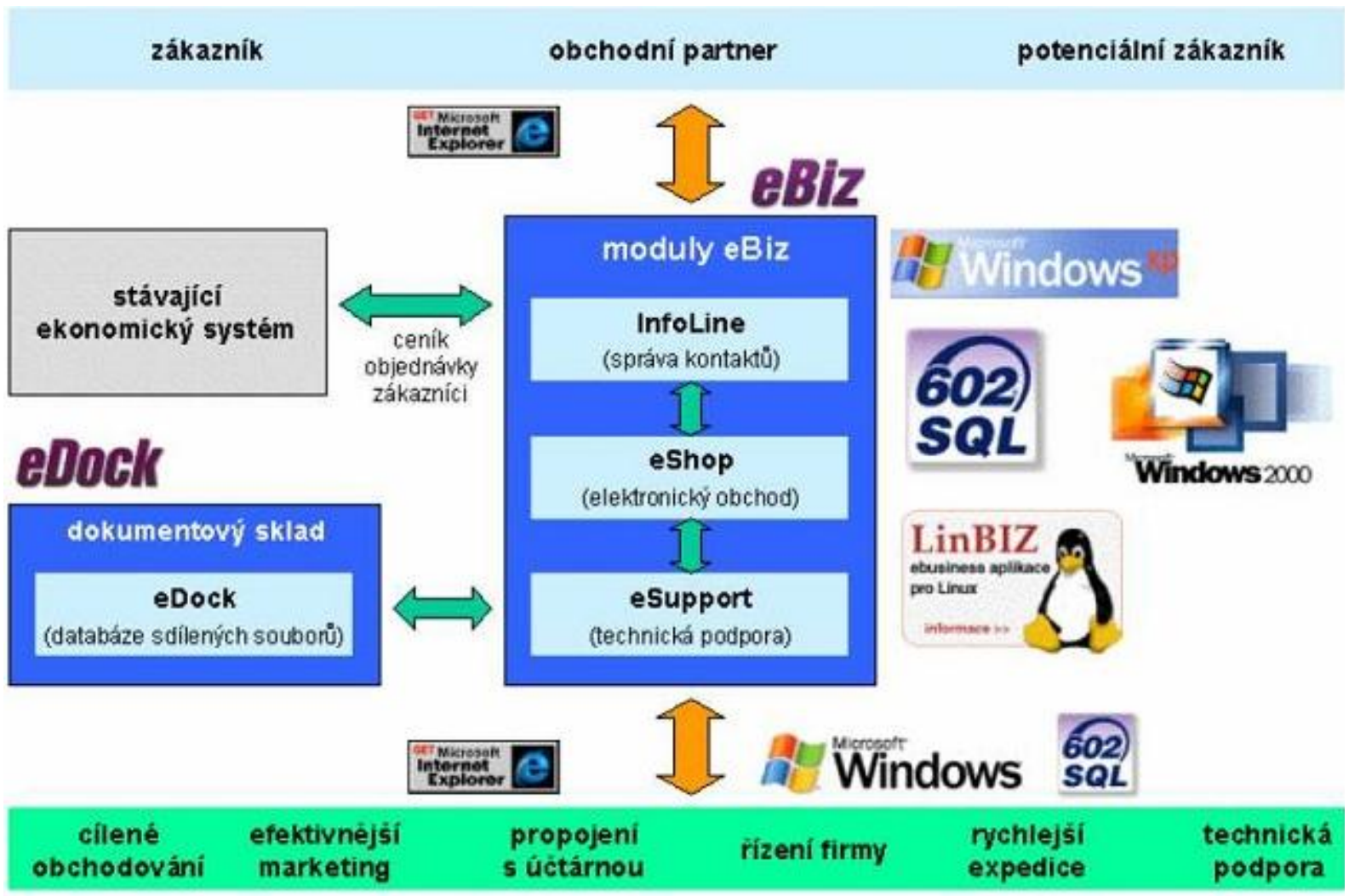

Obrázok 1: Vzájomné prepojenie modulov eBIZ

\section{InfoLine}

Je SFA (Sales Force Automation) aplikácia pre efektívne získavanie, správu a evidenciu obchodných kontaktov, vedenie obchodných prípadov a komunikácia so zákazníkmi a obchodnými partnermi prostredníctvom elektronickej pošty. InfoLine umožňuje základný nástroj pre evidenciu kontaktov a telemarketing. Vstupné dáta je možné zadávat' ručne, alebo je možné ich preberat' z elektronickej pošty a eShopu.

Systém InfoLine je vhodný všade tam, kde sa pracuje s dátami, informáciami o zákazníkoch a obchodných partneroch. Umožňuje l'ahko založit' obchodné prípady a pracovat' s nimi až po 
ich ukončenie, vrátane priebežnej kontroly. Oproti tradičným a finančne náročným spôsobom oslovovania zákazníkov (napr. telefonický kontakt), InfoLine ponúka moderné a lacné spôsoby komunikácie prostredníctvom cielených zásielok elektronickej pošty, ktoré môžu byt' podl'a potreby generované automaticky. Celý proces, vrátane každého kontaktu, je zaznamenávaný v histórií. Na základe tohto sa vel'mi l'ahko dá zistit', v akom štádiu sa konkrétny obchodný prípad nachádza, čo už bolo uskutočnené, ktorý obchodník má na starosti danú objednávku a kroky, ktoré je ešte potrebné urobit' k dokončeniu objednávky.

Produkt InfoLine principiálne vychádza zo zákazníckej databázy, v ktorej zachytáva všetky subjekty (zákazníkov) prichádzajúcich do styku s firmou. Priradenie konkrétnemu záznamu zákazníckej databázy sa zakladajú do jednotlivých obchodných kontaktov. Prepojením InfoLine s prenosovými možnost'ami internetu sa ponúkajú možnost' lacnej komunikácie so zákazníckou databázou. Možné je odosielat' jednotlivé aj hromadné e-maily. Zákazníkov je možné vyberat' hromadne, alebo s možnost'ou filtrovat' podl'a príslušnosti do kategórie.

Modul InfoLine možno prepojit's modulmi eShop a eSupport tak, že pri jednotlivých kontaktných osobách máte $\mathrm{k}$ dispozícii údaje o uskutočnených objednávkach v eShope, alebo o otázkach položených v diskusnom fóre eSupportu. [1], [2]

\section{eShop}

Tento modul umožňuje vystavit’ tovar na vlastných webových stránkach a potom prijímat' objednávky zákazníkov z prostredia internetu. Podporuje elektronický príjem platieb aj elektronické prepojenie s ekonomickými systémami. eShop, je modul umožňujúci vytvorenie „virtuálneho“ internetového obchodu. Môže podporovat' predaj vo vlastnej predajnej sieti (B2B), čo môže napríklad riadit' vaše obchodné vzt'ahy k predajcom vašich produktov. eShop je tiež schopný riadit' predaj priamo koncovým zákazníkom (stratégia B2C). eShop sa skladá $\mathrm{z}$ rady komponentov, cenníka tovaru, prehl'adu skupín tovarov, zákazníckych zliav, prehl'adu zákazníkov, nastavenia platobných a dodacích podmienok, komponentu pre výpočet štatistiky a d’alších. Základné funkcie modulu eShopu poskytujú prácu s cenníkmi, spracovanie objednávok, vytváranie štatistík; nutné sú aj služobné manipulácie, administrácia modulu. Prístup ku týmto všetkým funkciám je riadený prostredníctvom internetového prehliadača. Modul eShop môže pracovat' ako nadstavba nad akýmkol'vek ekonomickým, informačným systémom. Flexibilita modulu spočíva v nezávislosti na rozsahu a štruktúre položiek cenníku. [2]

Pre zákazníka je dôležitá dobrá orientácia v ponuke. Je teda dôležité, aby elektronický obchod umožnil zákazníkovi jednoducho nájst' požadovaný tovar a takisto možnost' objednat' si ho. eShpo preto disponuje príslušnými vyhl'adávacími nástrojmi. Umiestnenie najatraktívnejšieho tovaru na najviac viditel'nom mieste môžete zaistit' zaradením do tzv. ,top listu“. Pre zákazníka je takisto aj dôležitá možnost' platieb. Zákazník si môže vybrat' z viac spôsobov platieb a dopravy tovaru. Modul podporuje, okrem štandardných spôsobov platieb tiež elektronické (on-line) spôsoby platby. Elektronickým spôsobom možno zatial' platit' cez eBanku, platobnú bránu CitiConnect a Paegas GSM Banking.

Na každú novú objednávku v eShope je obchodník vždy upozornený elektronickou poštou. Spracuje ju a zároveň elektronicky predá podklady pre fakturáciu. Zákazníkovi je obratom d’alšou poštovou zásielkou zaslaná informácia o akceptovaní jeho objednávky. Vd’aka integrácii jednotlivých modulov eBizu, môže byt' v module InfoLine každá objednávka ihned' automaticky priradená k údajom o zákazníkovi. Okamžitý stav zákazníckeho obchodovania ukazujú štatistiky. Modul zaznamenáva a vyhodnocuje podklady pre rad dôležitých štatistických údajov, celkové obraty v čase, obraty podl'a zákazníkov, podl'a položiek cenníku atd’. Obchodník tak má v štatistikách k dispozícií potrebné podklady pre prípravu obchodnej stratégie. Prenositel'nost' dát medzi počítačmi a tiež ich zálohovanie 
umožňuje funkcia exportu dát. Exportovat' možno zoznam všetkých objednávok, všetkých zákazníkov, alebo iba aktualizované zoznamy. Všetky údaje sa ukladajú vo formáte CSV (Comma Separated Values).

\section{eSupport}

Je modul, ktorého úlohou je zhromažd'ovat' požiadavky zákazníkov a ponúkat' návody ku ich riešeniu. Jeho úlohou je teda riešit' predpredajnú a popredajnú podporu zákazníkov týkajúcu sa riešenia technických problémov, dokumentácie, námetov a iných informácií. Základom činnosti modulu je znalostná databáza (FAQ) umiestnená a dostupná na webe. Jej obsah vzniká indexovaním l’ubovol'ných požiadaviek zákazníkov a odpovedí na ne. Modul d'alej prostredníctvom internetového prehliadača sprostredkuje prístup ku všetkým súvisiacim funkciám (teda aj administrácii nastaveniu prostredia, vytváraniu a zaradeniu tém, odpovedanie na otázky a d'alších). Modul umožňuje poskytovanú technickú podporu členit' do viac úrovní podl'a autentifikácie žiadatel'a (či sa jedná o náhodného návštevník, koncového zákazníka, predajcu atd'.). Zamestnanci firmy majú okamžitý prístup ku otázkam a odpovediam vo všetkých problémových okruhoch. Majú k dispozícii aj rýchle vyhl'adávanie podl'a tém aj fulltextové vyhl'adávanie položením požiadavky na znalostnú databázu. Užívatelia registrovaný zo štatútom „pracovník technickej podpory“ majú možnost' jednoduchým postupom radit' často opakované otázky a odpovede na ne do zoznamu často kladených otázok (FAQ) a zviditel'nit' ich tak na webe. Informácie súvisiace s technickou podporou umožňuje modul eShop l'ahko zdiel'at', napríklad u oddelených pracovísk. Pretože je všetko okamžite dostupné na webe, odpadá nutnost' rozosielania informácií elektronickou poštou.

Typické využitie modulu eSupport žiadatel’om (zákazníkom) v prípade vzniknutého problému by mal mat' nasledujúci postup:

1. Najskôr by sa mal žiadatel' pozriet' do okruhu FAQ. Tam sú popísané typické problémy, ktoré sa už v súvislosti s tovarom, alebo službou vyskytli a ku každému z problémov je hned' predostreté riešenie.

2. Pokial' medzi často kladenými otázkami, žiadatel' odpoved' na svoj problém nenájde, prejde na d'alší stupeň, k diskusnému fóru. Tu predkladajú žiadatelia svoj problém najširšiemu fóru ostatných užívatel'ov aj pracovníkov technickej podpory. Námet k riešeniu problému sa vel'akrát vynorí už len pasívnym čítaním popisov problémov a reakcií čitatel'ov. Pokial' nie, žiadatel' sám popíšte problém a sledujte, či na neho niekto zareaguje.

3. Poslednou možnost'ou, ked' neuspejete ani vo FAQ ani v diskusnom fóre, je priame položenie otázky odborníkom z technickej podpory. Žiadatel' si otvorí formulár pre položenie otázky, v ňom vyberie vhodnú tému a špecifikuje požiadavku; tá sa potom bezprostredne odošle k riešeniu technickej podpore. Pracovník technickej podpory zodpovedný za danú tematiku dostane elektronickou poštou upozornenie, že do ním spravovanej témy niekto vložil novú požiadavku. Pracovník sa pripojí k eSupportu, novo položenú požiadavku preštuduje a odpovie na ňu. Odpoved' sa elektronickou poštou odošle na adresu žiadatel'a. Otázka a odpoved' na ňu môžu byt' tiež automaticky vložené medzi príspevky do diskusného fóra vybranej témy, alebo sa riešený problém môže pridat' aj medzi témy FAQ. Tým sa informácie sprístupnia všeobecne pre všetkých užívatel'ov eSupportu (aj neregistrovaných).

Možnosti nasadenia pracovného modulu je celá rada. Typické nasadenie je však nasledovné:

1. Náhodní (anonymní) žiadatelia majú k modulu eSupport prístup len do zoznamu často kladených otázok (FAQ).

2. Užívatelia využívajúci platenú technickú podporu, môžu klást' otázky iba do jedinej témy všeobecného diskusného fóra. 
3. Iba registrovaní užívatelia majú prístup do tém v platenej časti diskusného fóra.

Pracovník technickej podpory je registrovaný užívatel', ktorému administrátor nastavil špeciálne oprávnenia. Taký pracovník má na starosti jednu, alebo viac tém, do ktorých môžu byt' vkladané otázky. Pokial' otázka príde priamo pomocou elektronickej pošty, alebo v InfoLine či v diskusnom fóre, pracovník sa pokúsi nájst' riešenie a na otázku kvalifikovane odpovedat'. Modul eSupport je potrebné, ako každý počítačový program, nastavit' a počas chodu nastavenia upravovat' a udržiavat'. K tomu je vyčlenená aspoň jedna osoba s právami administrátora, ktorá modul udržuje, administruje. Nástrojom administrátora je internetový prehliadač. Z neho má na základe svojho práva prístup ku všetkým potrebným konfiguračným dialógom. Tu sa postará o registráciu užívatel'ov a pridel'ovanie ich práv, môže zakladat' FAQ témy, diskusné témy a tiež zaist'uje archiváciu diskusných príspevkov. Otázky a odpovede na danú problematiku sa automaticky priradia k žiadatel'ovi do aplikácie InfoLine. Tým sa v InfoLine zbiehajú nitky problémov, ktoré sa vyskytli v rôznych firmách. V prostredí InfoLine jednoducho môžete ku každej firme nájst' problémy, ktoré ste so zamestnancami firmy riešili. Netýka sa to iba problémov riešených platformou modulu eSupportu, ale tiež problémov korešpondenčne riešených elektronickou poštou, alebo telefonicky. [2]

\section{Záver}

Aplikácia eBiz od spoločnosti Software602, a.s, prináša možnost' ako výrazne zjednodušit' a zefektívnit' vel'kú čast' obchodných procesov vo firme. Takisto poskytuje aj jednoduchú a úspornú komunikáciu so zákazníkmi. V neposlednej rade plynú výhody aj pre zákazníka, či už v podobe rýchlejšieho vybavenia jeho požiadaviek, alebo v podobe poskytnutia technickej podpory.

\section{Použitá literatúra}

[1] SUCHÁNEK, PETR. Podnikání a obchodování na internetu. 2008. ISBN 978-80-7248458-4.

[2] eBIZ. [online]. [Citované 2012-04-19]. Dostupné na: < http://www.602.cz/datainc/produkty/_ebiz/index.htm>

[3] FAQ. Wikipédia. [online]. Dostupné na: <http://cs.wikipedia.org/wiki/FAQ>

[4] Spoločnost' Software602 a.s. [online]. Dostupné na: <http://www.602.cz/>

\section{Grantová podpora:}

/KS/2012 inštitucionálny výskum: Analýza citlivosti počtu kontaktných miest k nákladom plynúcim z poskytovania UPS 